\title{
Multianalytical approach for the analysis of the Codices Millenarius Maior and Millenarius Minor in Kremsmuenster Abbey, Upper Austria
}

\author{
Bernadette Frühmann ${ }^{1 *}\left(\mathbb{D}\right.$, Federica Cappa ${ }^{1}$, Wilfried Vetter ${ }^{1}$, Manfred Schreiner ${ }^{1}$ and Father Petrus ${ }^{2}$
}

\begin{abstract}
Two precious Carolingian manuscripts kept in the library of Kremsmuenster Abbey in Upper Austria were subject of investigation. The well-known Codices Millenarius Maior (Inv. No. CC Cim 1, Fig. 1a) and Millenarius Minor (Inv. No. CC Cim 2, Fig. 1b) were studied within the framework of the Centre of Image and Material Analysis in Cultural Heritage (CIMA) in Vienna. The manuscripts are especially famous for their precious and colorful miniatures of a very early medieval period. The aim of the work was the material identification (colors and inks) used for the make-up of the two codices in order to gain a better understanding of their evolution and their provenance. The instrumentation available in the CIMA laboratories allowed performing in situ measurements using non-destructive and non-invasive analytical methods. The investigations comprised a combination of three complementary methods: X-ray fluorescence analysis (XRF), Fourier transform infrared spectrometry in the reflection mode (rFTIR) and Raman spectrometry. In addition to the identification of the pigments and inks also a detailed characterization of the parchment concerning its manufacturing process was achieved by that combination. The identification of calcium carbonates on the surface of the parchment is an indicator for the liming or whitening of the animal skin, whereas the polishing process of the parchment surface with pumice stone, left traces of silicates, detected by rFTIR. The combination of XRF and Raman spectrometry enabled the characterization of black/brown inks in the text revealing the usage of iron gall inks. For the red inks applied for text and initials vermilion and red lead were applied in both codices. Furthermore, the pigment palette used for the illumination included: lead white, orpiment/realgar, red lead, vermilion and red iron oxides as well as azurite and indigo, together with the rather rare copper chloride hydroxide. Furthermore, in both gospels the application of metal leaves as well as powders made of silver-copper and gold-copper alloys could be determined by XRF on several folios.
\end{abstract}

Keywords: Medieval manuscripts, Pigments, Inks, XRF, rFTIR, Raman

\section{Introduction/background}

During the last decades a particular collaboration between representatives of various humanities such as philology, art history and conservation-restoration on the one side and natural scientists on the other has been established, completed by a co-operation with computer vision specialists. Simultaneously the booming development of analytical methods has offered the possibility to

\footnotetext{
*Correspondence: b.fruehmann@akbild.ac.at

${ }^{1}$ Institute of Science and Technology in Art, Academy of Fine Arts Vienna, Schillerplatz 3, 1010 Vienna, Austria

Full list of author information is available at the end of the article
}

use a great number of new instrumental micro-analytical techniques with non-sampling and in situ applicability for the analysis of written heritage objects. In order to give this collaboration a solid structure, the Centre of Image and Material Analysis in Cultural Heritage (CIMA) in Vienna [1] was established in 2014 with the HRSM-project [2] running from 2014 until 2017 with the aid of the Structural Fund for Austrian Higher Education.

Within this framework a series of historical manuscripts of various libraries selected by philologists were examined. The selection comprises badly preserved or rewritten manuscripts (palimpsests) on the one hand, and manuscripts with a remarkable design on the other, 

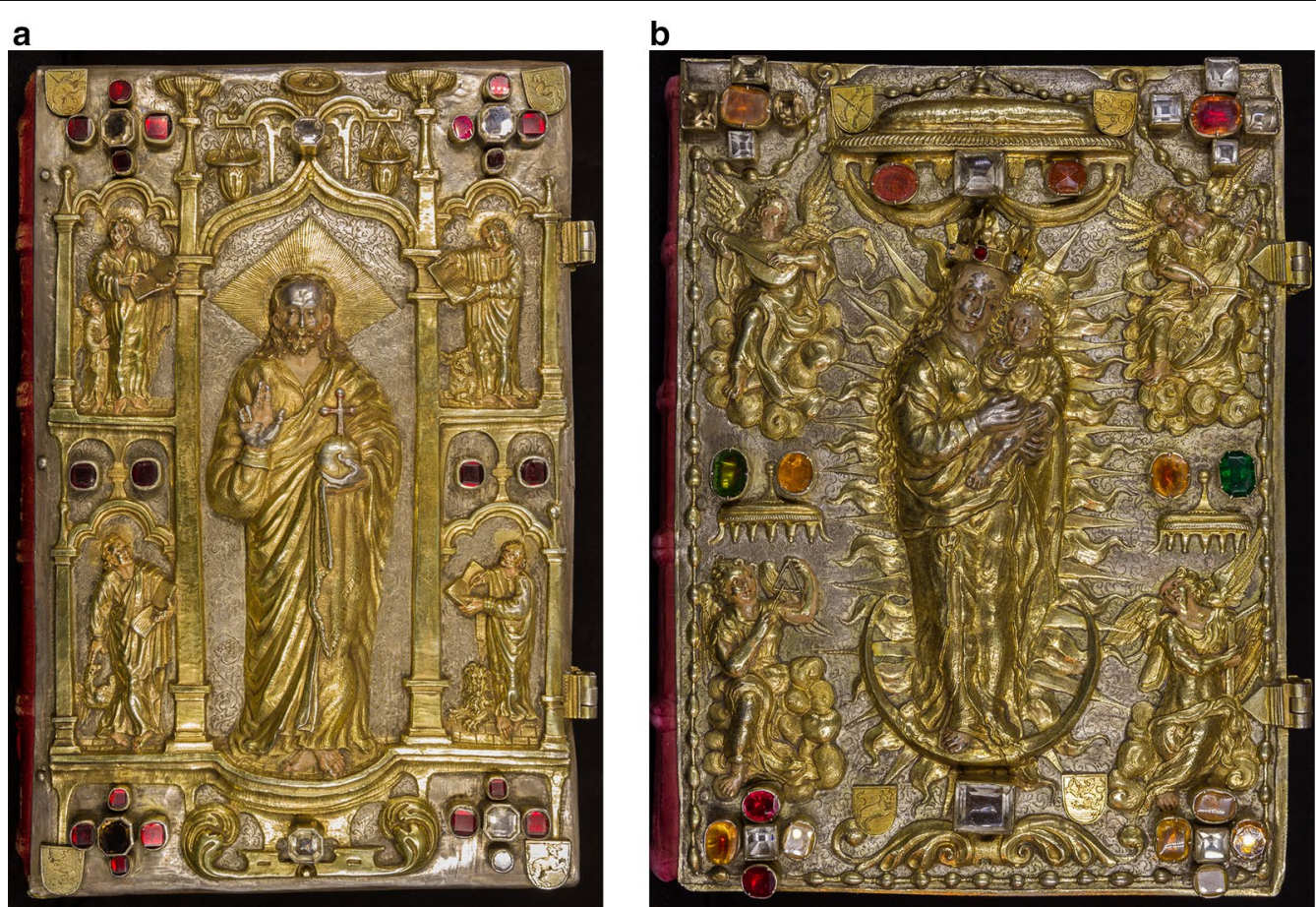

Fig. 1 The magnificent (secondary) covers of the Codices Millenarius Maior (a) and Millenarius Minor (b). The silver plates are partly gilded and decorated with precious gemstones. Codex Maior shows the Lord of the World with the four evangelists, whereas the cover of the Codex Minor is decorated with a representation of Saint Mary with Child, surrounded by four angels (Stift Kremsmünster, Julius Engel)

deriving from the 8 th to the 14th centuries. The material investigation aims to determine the composition of inks and pigments used for writing and illuminating, as well as the characterization of the support material. Besides chemical analyses, multispectral imaging was carried out to improve the legibility of historical texts. With all this information philologists and art historians are studying these objects. The data of material analysis will help to classify the manuscripts and their making. The final objective of the research is to compare the data gained to reveal correlations within data stemming from multiple modalities and, in general, to make new scholarly and scientific findings.

In this paper the results of investigations for two codices from the Carolingian period are presented. The examination of such early manuscripts has been rarely attempted, possibly due to extreme care in their administration which gives preferences to the preservation over the knowledge of the material aspects used for the manufacturing. Conferring to scientific literature, only a small number of analytical studies are known on manuscripts dating in this period [3-6].

Conferring to the origin and history of Carolingian art it was meant to be an artistic style which is outstanding in contrast to the others of former periods. The successors at this time wanted to establish cultural cohesion and political stability all over the empire. This led to the flowering of culture known as the Carolingian renaissance, which had their prosperity between 780 and 860 A.C. [7]. As a consequence there was a standardization of texts to make them easily legible as well as an exceptional usage of illuminations, which are heavily painted works with a naturalistic rendering of figures along with the opulent use of gold, silver and purple. The script known as Caroline minuscule was also part of the reform movement [8]. Luxury Carolingian manuscripts were intended to have treasure bindings like ornate covers in precious metal set with jewels around central carved ivory panels. Precious examples of this period are two manuscripts, the well-known Codices Millenarius Maior (Inv. No. CC Cim 1, Fig. 1a) and Millenarius Minor (Inv. No. CC Cim 2, Fig. 1b). Both codices are kept in the library of Kremsmuenster Abbey in Upper Austria. They are prepared in a highly sophisticated way and also richly decorated and illustrated (Fig. 1). With a fascinating past the two manuscripts are a prominent example for the application of the new Carolingian style.

According to historical tradition, in 1777 the papal nuncio Giuseppe Garampi attended the 1000th anniversary celebration of the Abbey. When he got aware of the 
older of the two codices, he proclaimed: "Vere hicce millenarius codex est!". Although his dating later proved to be somewhat too early, its proclamation lead to the name of codex CC Cim 1. Codex Millenarius Maior (henceforth: MMA) is a Gospel plenary, containing the complete text of the four Canonical Gospels [9]. They are preceded by the usual canon tables and introductory texts. Usually, it is assumed that it originates from the scriptorium of Mondsee Abbey not far from Kremsmuenster [10]. MMA happens to be the oldest of altogether three manuscripts deriving from this monastery (from where Kremsmuenster Abbey may have been founded) and dates from the early ninth century. The Gospels are written in two columns with black ink in the solemn Carolingian Majuscule (Uncial), the additions in the denser Capitalis Rustica. The beginning and the end of each part are composed in Capitalis Quadrata and held in red and green. The regularity of the writing suggests a single scribe. The text is a variant of the northern Italian Vulgata, influenced by the tradition of the Vetus Latina.

As is known, MMA is especially famous for its four double-sided evangelist miniatures before their respective Gospel [11]. On the writing desk of the evangelists, the incipit of the corresponding Gospel is cast in fine minuscule, which is significant for the dating. Apart from that, the decoration of the book is limited to the initials at the beginning of each gospel.

Due to the first Ottoman siege of 1529, the metal applications of the last known medieval binding had to be fused in order to enable the monastery to pay the tax levied by the emperor to finance the war. After this event, MMA was left unbound for at least 70 years [12], leading to the damage of the manuscript's first three layers (folios 1-12). Around the year 1600, they were rewritten on paper by Prior Leonhard Wagner, who still disposed of the original parchment leaves, as evidenced by an imprint of the last canon table on folio 10r which exactly corresponds to Wagner's division. A paper folio with the texts of John 20:31-21:14 was also added at the end. The rest of the Gospel of John is missing. Consequently, today MMA contains 330 parchment and 47 paper folios.

A new cover made of pressed, partly gilded silver with 26 stones was given to the codex before the year 1600 under Abbot Johannes Spindler (1589-1600). His coat of arms occupies the corners of the front cover. Central is the figure of the Lord of the World, to whom Kremsmuenster Abbey has been dedicated since its foundation. In 1953, the red velvet of the book covers was replaced by red goat leather. Later on and according to a medieval

${ }^{1}$ Which means: "This one is definitely a millennial codex". custom, four charters were entered on empty pages in minuscule copies of the 12th century.

Even today, MMA is still in liturgical use. In remembrance of the monastery's founder, a solemn requiem is held every year on the 11th of December, in which the Gospels are sung from MMA.

In contrast to MMA, the younger Codex Millenarius Minor (henceforth MMI) is no longer in practical use except for rare exhibitions [13]. This manuscript represents a plenary in Carolingian minuscule. It is commonly dated to the last quarter of the ninth century and was given to the monastery under Abbot Snelpero (888-893). Written by various hands and probably only later combined to a plenary, MMI contains 224 parchment and 21 paper folios. Of the miniature paintings only Saint Mark is completely preserved, while the bottom part of Saint John's miniature are lost. Here, too, the decoration of the book is limited to the initials at the beginning of the Gospels. Completely preserved are the canon tables at the beginning of the book. At the end of the manuscript (fols. 207r-225r) an instruction of the Gospel readings is added-a clear indication that the book was used for the holy sacrifice of the mass.

Similarly to MMA, some charters were included into MMI, and-for us even more interesting-a treasure inventory deriving from the year 1032, in which one entry has been erased. The restoration of the legibility of this erased text is one of the desiderata of our project.

The cover of MMI resembles the one of MMA. Instead of the redeemer, however, the front cover shows a representation of Saint Mary with Child. Between the silver panel and the wooden covers some relics are stored, including those of the monastery's patron Agapitus. These relics were inscribed in the 13th century. In the inventory of the relics dating from the 10th/11th century, also present in the codex, Agapitus is not mentioned.

Our analysis of the two codices described above mainly aims at the identification of the colors and inks used for their make-up. From its results a better understanding of their evolution can be expected, especially regarding their provenance.

In order to study the materials used for manuscripts of this kind, non-destructive and non-invasive techniques are essential. This also implies the possibility of performing the measurements in situ. Since the two codices were studied during different phases of the project, different analytical techniques were accessible for the analyses. As these codices were only available for the investigations in a limited period of time it was not possible to do all examinations that would have been necessary and it was essential to focus on capable methods.

Our investigations comprised a combination of several complementary methods: on the one hand, X-ray 
Fluorescence analysis (XRF) was used for elemental analysis; on the other hand Fourier transform infrared spectrometry in the reflection mode (rFTIR) and Raman spectrometry were performed in order to obtain compound specific information. Thus, codex MMI was analyzed by XRF and rFTIR spectrometry (the Raman instrument was not yet available), whereas XRF and Raman spectrometry were applied in the case of codex MMA (because of the limited time it was not possible to do rFTIR measurements for these investigations so far). In doing so, the XRF analysis was always carried out first to classify the elements present in the areas of interest and give preliminary information for the interpretation of the compound specific data to be gained in the complementary analyses $[14,15]$. Comparable instruments [16-20] as well as additional methods and other combinations of those [21-24] were used for the research of manuscripts in other projects or research groups.

\section{Methods/experimental}

Due to the different period of the investigations the XRF analysis for the elemental identification of the pigments applied for the illuminations as well as the inks used for the text were carried out with two different portable XRF instruments available at the Institute of Science and Technology in Art, Academy of Fine Arts Vienna (ISTA). Both are equipped with a primary beam spot size of about $1 \mu \mathrm{m}$ in diameter and two laser pointers for a precise positioning. These instruments are mounted on a tripod in order to measure in a position most suitable for the object. X-ray radiation has a certain penetration depth because of the comparatively high energy of the primary beam. This leads to the obstacle, that the element detection does not only refer to the surface layer (e.g., pigment or ink), but is the result of all elements present in all layers including the components of the parchment and the possible material of the verso-side of the folio. As the analyses are carried out in air, elements with an atomic number lower than silicon $(\mathrm{Si})$ cannot be detected. To describe this, the well-known pigment ultramarine blue can be taken as a good example, as its elemental composition is based on a sodalite cage of sodium $(\mathrm{Na})$ and silicon $(\mathrm{Si})$, elements which cannot be detected in air at all. In general, the spectrum obtained has to be compared with the one of the (bare) support material, here parchment. The correlation to an ink or pigment is not always an easy task; sometimes the results are even impossible to verify.

Codex MMI was examined with our self-built XRF instrument, which was developed and built within the framework of a Ph.D.-thesis for the application in the fields of art and archaeology [25]. It is equipped with an X-ray rhodium ( $\mathrm{Rh}$ ) tube with a maximum power of
$50 \mathrm{kV}$ and a silicon drift chamber detector. The measurement parameters chosen for the relevant manuscript analyses are a tube voltage of $35 \mathrm{kV}$ and a tube current of $0.8 \mathrm{~mA}$ for $100 \mathrm{~s}$ acquisition time.

For codex MMA a new instrument, purchased during the HRSM project, was employed. The X-ray spectrometer ELIO [26] is a device well designed for the application in the field of arts. The system head consists of a 4 Watt $\mathrm{X}$-ray rhodium $(\mathrm{Rh})$ tube together with a silicon drift chamber detector (SDD) of an active area of $25 \mathrm{~mm}^{2}$. The settings for the measurements of the codex were of $40 \mathrm{kV}$, $20 \mu \mathrm{A}$ and $100 \mathrm{~s}$ measurement time. In previous investigations it was possible to study objects which were investigated with the self-built XRF instrument to compare the results of these two devices. The results fitted perfectly to allow a direct comparison of these two instruments. So far there was no opportunity for Codex MMI to do further investigations.

In addition to XRF, FTIR-spectrometry was applied for codex MMI in order to gain also information about the compounds or even some organic mixtures as well as binding media. The available instrument is a portable Bruker ALPHA FTIR-spectrometer [27] with a spot size of approximately $4 \mu \mathrm{m}$ in diameter. Total reflection spectra (specular and diffuse reflection) were collected in situ in the range of $4000-400 \mathrm{~cm}^{-1}$ with a resolution of $4 \mathrm{~cm}^{-1}$ over $64-128$ scans. The background was acquired using a gold mirror as reference sample. The total reflection spectra were transformed to absorption index spectra applying the Kramers-Kronig algorithm [28], which is included in the software package OPUS, version 6.5, used for controlling the ALPHA instrument as well as the data acquisition and evaluation. After the transformation, a baseline correction was carried out to the absorption index spectra. For evaluation the spectra were compared to the database IRUG (Infrared and Raman Users Group [29]) with spectra mainly obtained in the transmission mode as well as to a database of the ISTA with spectra obtained from the individual material collection in transmission and reflection mode.

However, a great disadvantage of rFTIR is that inks such as carbon black or iron gall inks or mixtures of both cannot be identified. Raman spectrometry, acquired mainly for the analysis of these inks in a later period of the project, was performed for the analysis of the codex MMA. This compound specific method, similar to FTIR spectrometry, was carried out in situ with the ProRaman-L-Dual-G [30], a fully integrated and transportable instrument. The excitation sources applied for the investigations were Diode Lasers at $785 \mathrm{~nm}(\sim 350 \mathrm{~mW})$ and $532 \mathrm{~nm}(\sim 50 \mathrm{~mW})$ with narrow line-widths of 2.0 and $1.5 \mathrm{~cm}^{-1}$, respectively. The instrument is based on a two dimensional CCD array detector, which is 

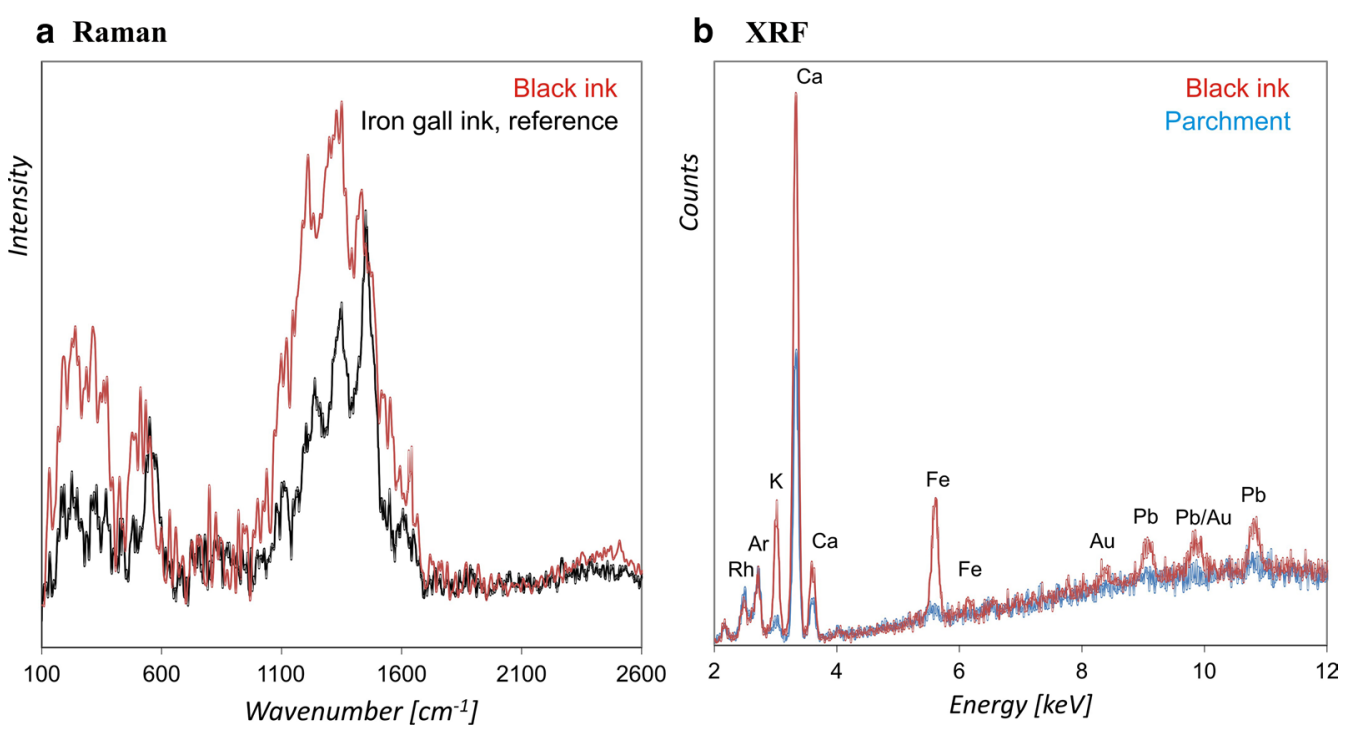

Fig. 2 Results of the measurements of the black ink on fol. 108r of Codex Millenarius Maior performed with Raman and XRF. a Raman spectrum of the black ink (red) and a reference spectrum of iron gall ink (black). b XRF spectrum of the black ink (red) in comparison to the parchment (blue), where $\mathrm{K}$ and Fe were detected. Lead $(\mathrm{Pb})$ seems to derive from the surface, as it was found in some parchment points, too

temperature regulated $\left(-60^{\circ} \mathrm{C}\right)$. To memorize the measurement spot, the instrument is equipped with an integrated microscope (1.3 Mpixel CMOS camera with an in-line LED illumination). The spot size of the excitation lasers is very small compared to XRF and rFTIR and varies depending on the applied laser as well as the objective lens of the microscope. Using an objective lens of, e.g., $40 \times$ magnification, the spot size is about $50 \mu \mathrm{m}$ in diameter for the $785 \mathrm{~nm}$ laser, whereas for the $535 \mathrm{~nm}$ laser the analyzed area is reduced to $35 \mu \mathrm{m}$ in diameter. The spectra were evaluated by comparison to a reference database of ISTA, created by mockups of the pigment collection in the institute.

\section{Results and discussion}

The aim of these investigations was to identify the inks as well as the pigments and binding media used for both codices. A comparison of the materials applied for both codices seems to be highly appropriate as their time of origin does not differ widely. Final evaluation has been obtained by combining the various results of the complementary analyses performed. Of each codex more than ten folios were examined, which were selected by philologists (either recto or verso of a folio). Main focus was given to folios with either text and initials or large illuminations at the beginning of the four Gospels.

\section{Parchment}

The selected areas of interest for the measurements on parchment were mostly located on the margins or between the columns to ensure that no ink, pigment, etc. is located on this point as well as on the reverse side of this area (important for XRF investigations).

The main elements detected in the parchment with XRF were potassium (K), calcium (Ca) and iron (Fe); sometimes traces of phosphorus $(\mathrm{P})$ and sulfur $(\mathrm{S})$ were identified as well. Small amounts of lead $(\mathrm{Pb})$ could be registered only in cod. MMA (fols. 18r, 108r, 111r, 175r, $276 \mathrm{v})$, whereas small intensities of silver $(\mathrm{Ag})$ were determined on some folios in both manuscripts (Cim. 1, fol. 278r; Cim. 2, fols. 9v and 183r). In cod. MMI two different types of parchment were characterized by rFTIR: some with calcium carbonate from whitening the support together with few silicates from polishing (fols. $9 \mathrm{v}, 17 \mathrm{v}, 73 \mathrm{v}, 111 \mathrm{r}, 167 \mathrm{v}, 183 \mathrm{r}$ ), others without these two materials (fols. 19v, 219v). Low values of potassium (K) are intrinsic for the chemical composition of the parchment as well as phosphorus (P) and sulfur (S). Iron (Fe) is certainly present due to the preparation (removal of the hair and polishing of the skin) [31]. Small amounts of lead $(\mathrm{Pb})$ are possibly from lead white-these folia appear in a pale shade-which cannot be confirmed here. The silver (Ag) amount can be attributed to the abrasion of the metal implementation of the initials on these folia. The surface treatment could not be confirmed by Raman analysis.

\section{Black ink}

The XRF measurements in the areas of the black ink yielded a higher intensity mainly of iron (Fe) and in 


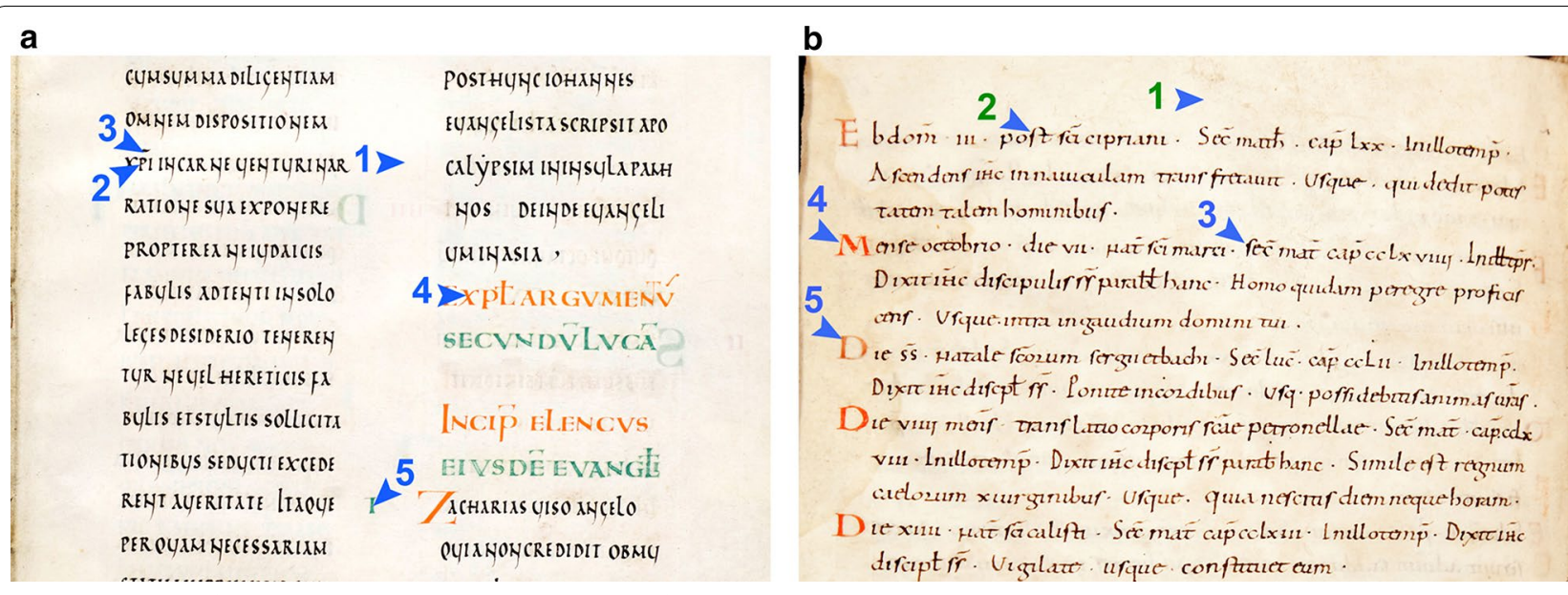

Fig. 3 Folio 168r of Codex Millenarius Maior (a) compared to folio 219v of Codex Millenarius Minor (b). The red ink used in Codex Maior (MP4) was identified as minium, whereas Codex Minor showed vermilion in MP4 and minium in MP5. The green ink in Codex Maior (MP5) was identified as a copper based ink by XRF. Due to high fluorescence interference no clear identification was possible with Raman spectrometry (Computer Vision Lab (CVL), Vienna University of Technology, DI Fabian Hollaus)

some cases for potassium $(\mathrm{K})$ as well. By Raman spectrometry, iron gall ink was verified (e.g. Cim. 1, fol. 108r; Fig. 2) [32-34]. With rFTIR spectrometry calcium oxalate $\left(\mathrm{CaC}_{2} \mathrm{O}_{4}\right)$ was detected in the black ink, which is most likely a metabolic product from the degradation of ink components by mold fungi (microbiological analyses have yet not been performed) [35].

Due to the dark-brown, almost black color of the text ink it is possible that the iron gall ink is mixed with carbon black. However, by the methods XRF and rFTIR it is not possible to detect this kind of writing material-carbon $(\mathrm{C})$ cannot be detected by XRF in air and it does not absorb mid infrared radiation. In general, Raman spectrometry would allow the identification of carbon black, but the interference with the bands of the support material (parchment) did not yield clear results. Therefore, a possible mixture of iron gall ink with carbon black cannot be excluded.

\section{Red and blue/green inks}

As mentioned before, the first letters at the beginning of each chapter in cod. MMA as well as in cod. MMI are done in red and green Capitalis Quadrata. The results for red inks clearly revealed differences: in cod. MMA only minium $\left(\mathrm{Pb}_{3} \mathrm{O}_{4}\right)$ was identified in the red text passages (except for fol. 1r, which is a later supplement), whereas in cod. MMI regularly vermilion ( $\mathrm{HgS}$ ) could be determined and just in a few cases vermilion mixed with minium. Figure 3 depicts an example for the different application of red and green inks in the two manuscripts.

In cod. MMA also green ink was applied as a writing material for headings and initials (Fig. 3a), in contrast to cod. MMI. In this case by XRF copper $(\mathrm{Cu})$ was detected as the main element, together with traces of calcium $(\mathrm{Ca})$ and lead $(\mathrm{Pb})$, which indicates the use of a copper based green pigment, possibly mixed with lead white and/or calcium carbonate to brighten up the color. Unfortunately, due to high fluorescence interference no distinct identification with Raman spectrometry (532 nm laser was used) could be achieved.

\section{Metal coatings}

Silver and gold coatings are present in both manuscripts, as can be seen in Fig. 4. The results of the XRF analyses always show applications of silver-copper and gold-copper alloys. Additionally, some chlorine $(\mathrm{Cl})$ and lead $(\mathrm{Pb})$ was registered, the later stems most likely from the red lines surrounding the gold and silver parts of the initials. In cod. MMI some areas show small amounts of arsenic (As), indicating the use of orpiment or realgar. A clear classification was not possible here, as no Raman instrument was available for these investigations. The reason for the blackening of silver areas lies mainly in the presence of hydrogen sulfide in the ambient atmosphere and/ or sulfur containing material in the parchment, which may have provided sulfur (S) for the formation of black silver sulfide $\left(\mathrm{Ag}_{2} \mathrm{~S}\right)$ [36]. The identified chlorine $(\mathrm{Cl})$ in these areas could be silver chloride $(\mathrm{AgCl})$, which might stem from poor preservation conditions or by incorrect restoration treatments of the past [37]. Additionally, it is also mentioned in the literature that varnish layers applied for protection can cause such darkening [38]. 
a

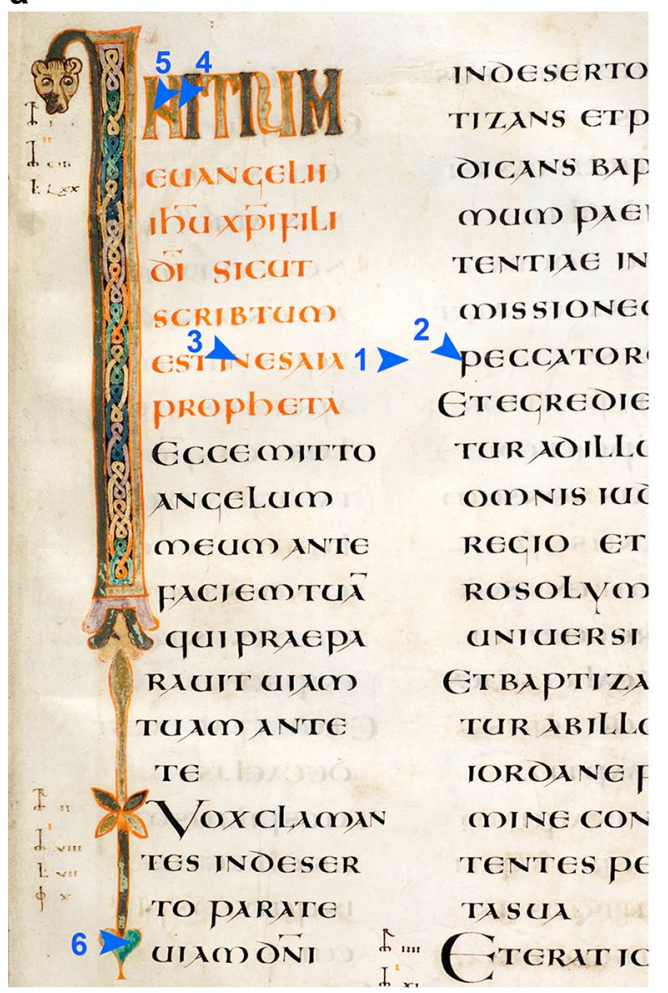

b

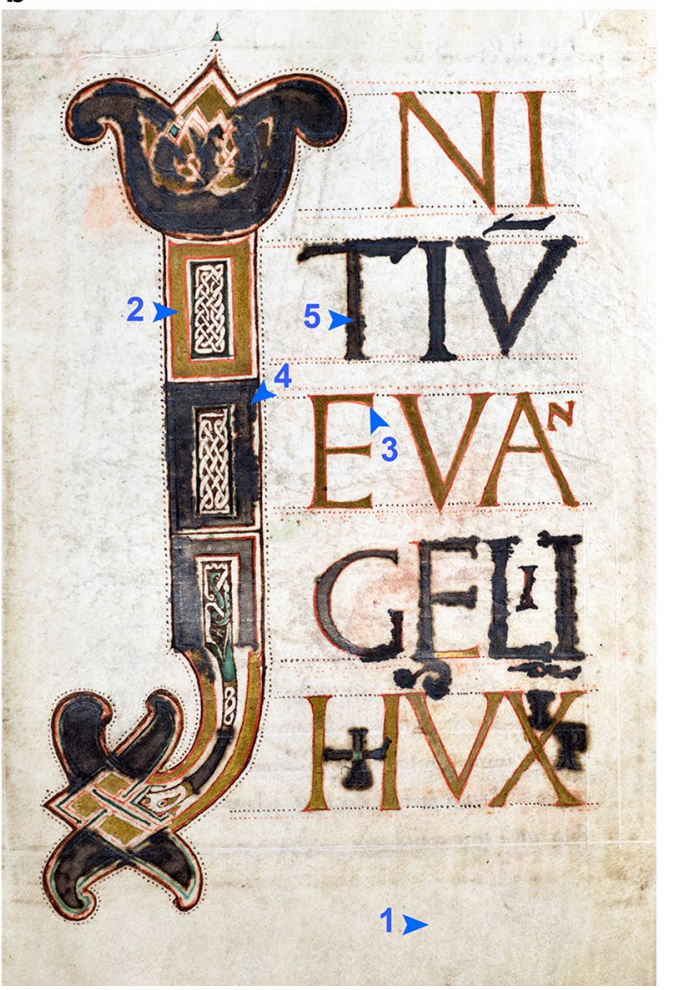

Fig. 4 Folio 111r of Codex Millenarius Maior (a) compared to folio 74r of Codex Millenarius Minor (b). The red frames for the letters can be seen clearly in both figures. A difference in the blackening of the silver coatings between the two codices is visible, too (Computer Vision Lab (CVL), Vienna University of Technology, DI Fabian Hollaus)

\section{Materials in illuminations and decorations}

An outstanding feature of the two codices is the design of the miniature paintings at the beginning of each gospel. In cod. MMA each gospel starts with the evangelist painted on one folio with his attributes on the opposite side, whereas in Codex Millenarius Minor the saint is shown together with his symbol figure in one miniature painting (Fig. 5).

Nevertheless, the used pigments are very often identical. Lead white was identified in the white parts as well as in different areas to brighten up the color. In both codices orpiment/realgar could be determined as the yellow pigment, since sulfur (S) and arsenic (As) as main elemental constituents of orpiment were detected by XRF. Additionally, also iron (Fe) and small amounts of calcium (Ca) could be registered in one yellow area (Fig. 5a, saint MP1 and lion MP2) indicating a yellow ochre, which could not be confirmed with Raman spectrometry. Moreover, minium (red lead) was identified in the orange parts of the miniature paintings (Fig. 5a, saint MP2 and lion MP3). A comparison of all identified pigments in both codices is summarized in Table 1.

\section{Codex Millenarius Maior}

For cod. MMA the XRF results were complemented by Raman measurements. With this method some pigments used could be correlated to the colors. The red/ orange pigment, where $\mathrm{Pb}$ was detected with XRF, could be identified with Raman as minium (red lead). However, the dark red areas show a higher intensity for iron (Fe) in comparison to the parchment, which indicates iron oxide as pigment used, but a clear proof with Raman spectrometry could not be obtained. In the vivid blue parts of the paintings copper $(\mathrm{Cu})$ was detected by XRF and identified as azurite by Raman, whereas in the dark blue areas only calcium ( $\mathrm{Ca}$ ) and sulfur (S) were registered by XRF (Fig. 6a), probably used as gypsum to brighten up the color (Fig. 5a, saint MP4), but no indications for a blue mineral pigment were obtained. With Raman spectrometry the pigment applied could be confirmed as indigo (Fig. 6b). In the green areas of this codex (Fig. 5a, saint MP5 and lion MP8) copper $(\mathrm{Cu})$, sometimes associated with chlorine $(\mathrm{Cl})$, was detected, but no clear identification of the paint material could be achieved [39-41]. Similar difficulties occur in the case of the brown pigments, where by XRF just iron (Fe) was registered as 

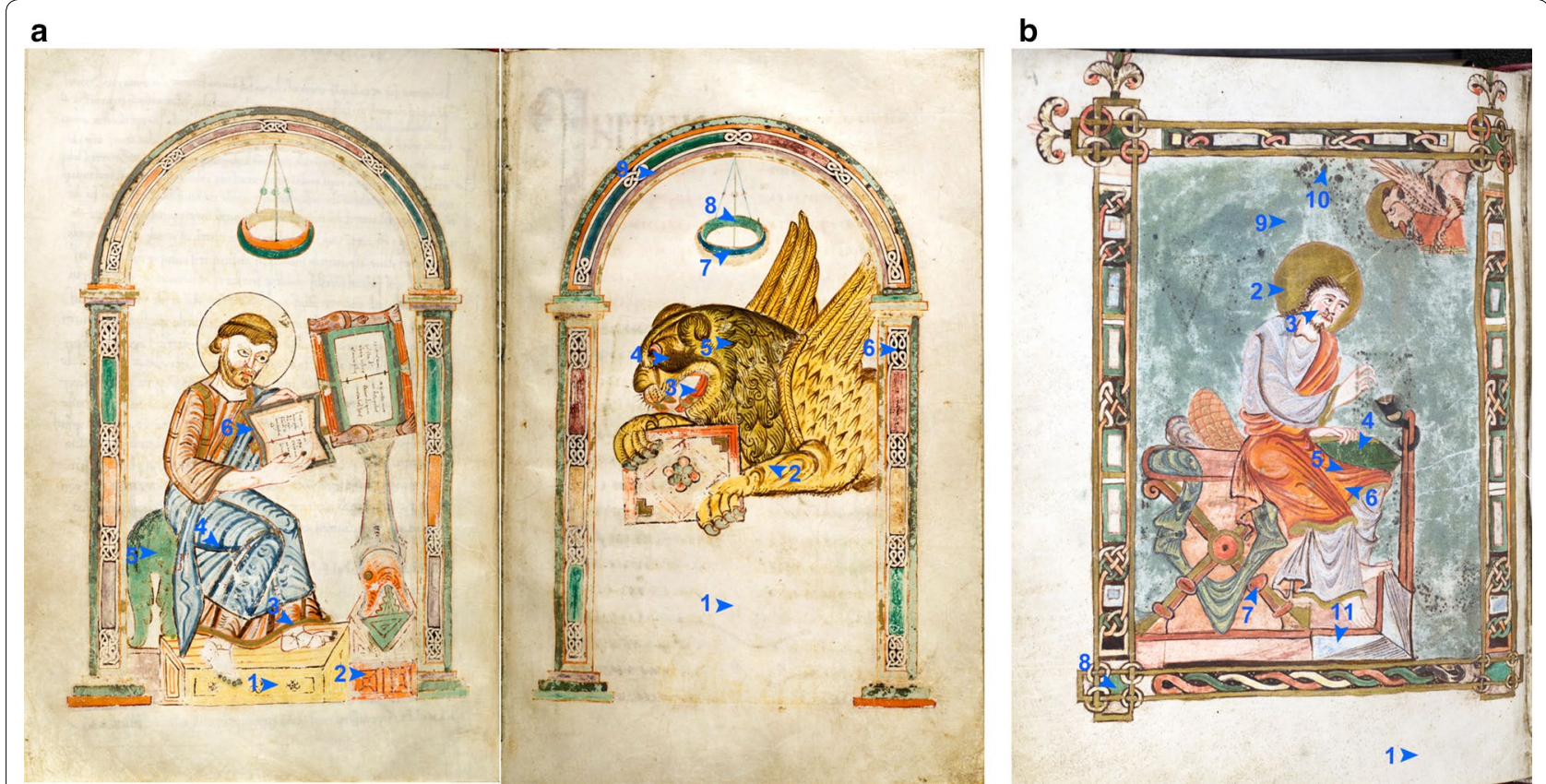

Fig. 5 a Folios 109v and 110r of Codex Millenarius Maior compared to (b) folio $73 \mathrm{v}$ of Codex Millenarius Minor. The similarities in the colors can be documented in the green areas as a copper based pigment, the red parts with minium as well as the yellow areas with orpiment/realgar (Computer Vision Lab (CVL), Vienna University of Technology, DI Fabian Hollaus)

Table 1 Identified pigments in the illuminations of the investigated manuscripts

\begin{tabular}{lll}
\hline Color & Codex Millenarius Maior & Codex Millenarius Minor \\
\hline White & Lead or calcium based pigments & Lead white $\left(2 \mathrm{PbCO} \cdot \mathrm{Pb}(\mathrm{OH})_{2}\right)$ \\
Yellow & Orpiment/realgar as well as iron oxide & Orpiment $\left(\mathrm{As}_{2} \mathrm{~S}_{3}\right)$ as well as iron oxide \\
Orange & Minium $\left(=\right.$ red led, $\left.\mathrm{Pb}_{3} \mathrm{O}_{4}\right)$ & Minium $\left(=\mathrm{red} \mathrm{led}_{1} \mathrm{~Pb}_{3} \mathrm{O}_{4}\right)$ \\
Red & Minium $\left(=\right.$ red led, $\left.\mathrm{Pb}_{3} \mathrm{O}_{4}\right)$ & Vermilion $(\mathrm{HgS})$ \\
Dark red & Iron oxide/ochre & Iron oxide $(\mathrm{FeO}(\mathrm{OH}))$ \\
Blue & Azurite $\left(\mathrm{Cu}_{3}\left(\mathrm{CO}_{3}\right)_{2}(\mathrm{OH})_{2}\right)$ & Lapis lazuli $\left(\mathrm{Na}_{8 \ldots 10}\left[\mathrm{Al}_{6} \mathrm{Si}_{6} \mathrm{O}_{24}\right] \mathrm{S}_{2 \ldots 4}\right)$ \\
Dark blue & Indigo $\left(\mathrm{C}_{16} \mathrm{H}_{10} \mathrm{~N}_{2} \mathrm{O}_{2}\right)$ & \\
Green & Copper based green pigment & Copper $(\mathrm{II})$-hydroxyl chloride $\left(\mathrm{Cu} \mathrm{Cl}_{2} \mathrm{Cl}(\mathrm{OH})_{3}\right)$ \\
Brown & Iron based brown pigment (brown ochre) & Iron based brown pigment $($ brown ochre $)$ \\
\hline
\end{tabular}

Due to rFTIR and Raman spectrometry a clear identification of similar pigments was not always possible; therefore, the chemical formulas are not mentioned

the main element, but no evidence for the used pigment was found (Fig. 5a, lion MP4 and MP5). In the purple area (Fig. 5a, lion MP9) the application of a red lake, e.g., madder mixed with azurite (blue), must be assumed, as small intensities of copper $(\mathrm{Cu})$ were detected with $\mathrm{XRF}$, but no Raman spectrum characteristic for an inorganic or organic paint material was obtained. Mixtures of blue pigments with organic colorants are proven in this period [3], but in this case they were not verifiable in a nondestructive way.

\section{Codex Millenarius Minor}

The combination of XRF and rFTIR spectrometry yielded to slightly different materials in comparison to cod. MMI, due to the fact that rFTIR and Raman spectroscopies use different absorption properties. rFTIR analyses proved the application of lead white in white parts, where lead $(\mathrm{Pb})$ was detected with XRF. This pigment could as well be found in different colored parts-especially red and blue areas-where it was applied to brighten the color. The most remarkable variations in the application of colors have been observed in the red areas. XRF analysis detected the elements mercury $(\mathrm{Hg})$ together with 

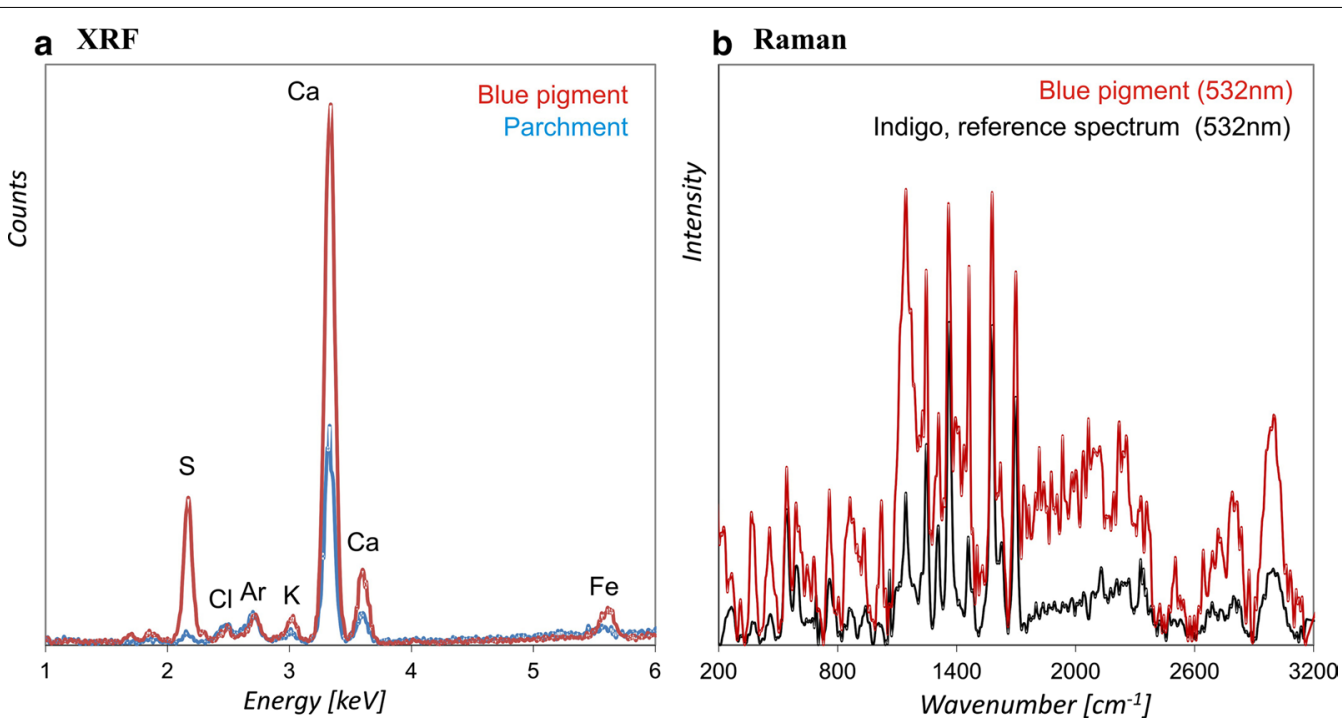

Fig. 6 Results for the measurements on folio 276v in a dark blue area of Codex Millenarius Maior, were indigo was identified. a XRF spectrum of the blue pigment (red) in comparison to the parchment (blue), where sulfur (S) and calcium (Ca) were detected (probably gypsum), but no indications for a blue pigment were found by XRF. b Raman spectrum of the blue pigment (red) in comparison with a reference spectrum of indigo (black)

\section{a rFTIR}

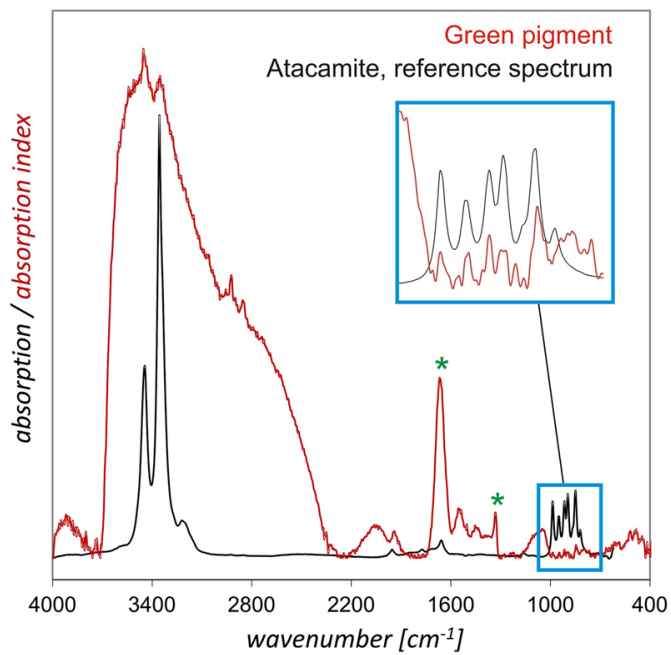

\section{b XRF}

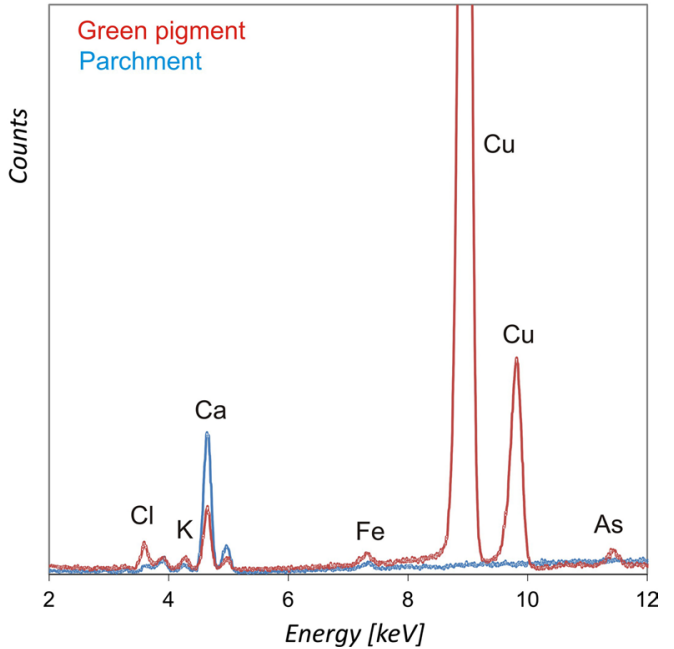

Fig. 7 Results for the measurements of the green pigment on fol. 17r of Codex Millenarius Minor. a rFTIR spectrum of the green pigment (red) in comparison to the 0 reference spectrum of atacamite (black). The characteristic bands for atacamite are very weak in the measured spectrum and are stretched in the enlarged section for improved visibility. The bands at 1670 and $1334 \mathrm{~cm}^{-1}$ (marked with asterisk) indicate calcium oxalate. b XRF spectrum of the same measurement point (red) in comparison with the parchment (blue). Copper (Cu) and chlorine (Cl) are clearly visible

lead $(\mathrm{Pb})$. Because of the interference of the L-lines of $\mathrm{Hg}$ and $\mathrm{Pb}$ together with sulfur $(\mathrm{S})$, this element is not always clearly detectable. Occasionally big amounts of iron $(\mathrm{Fe})$ were additionally registered. rFTIR spectrometry could specify these results as vermilion, mixed either with lead white (Fig. 5b, MP3) or, more probably, with minium (Fig. 5b, MP6). As rFTIR is not able to identify minium, this compound can only be assumed, if lead white is not visible. In parts with dark red the analyses show a mixture of vermilion, probably minium and iron oxide (Figs. 5b, MP5, 7). In the application of the blue color (Fig. 5b, MP11) lapis lazuli was verified by rFTIR. As this compound consists of elements with low atomic numbers, e.g. $\mathrm{Na}, \mathrm{Al}, \mathrm{Si}$, which scarcely can be detected with XRF in air, no indication for this pigment could be found in the XRF spectrum. Only lead $(\mathrm{Pb})$ was proofed 
here, which derives from the addition of lead white. For the green material XRF identified calcium $(\mathrm{Ca})$ together with copper $(\mathrm{Cu})$. In some parts additionally chlorine $(\mathrm{Cl})$ was detected, which yields to two different copper green pigments: one with and one without chlorine. rFTIR allowed the identification of copper (II) chloride hydroxide in specific measurement areas on folios with initials (Fig. 7), in combination with calcium oxalates, probably from microbiological degradation of the binding medium [41-43]. For the remaining measurement points on the folios of the saints (e.g. fols. 73v, 167v) the copper based pigment without chlorine could not be classified. However, no calcium oxalate was identified there. The brown pigment in this codex could be identified as umbra mixed with calcium carbonate, as XRF measurements detected calcium $(\mathrm{Ca})$ and iron $(\mathrm{Fe})$, and also low intensities of manganese (Mn).

\section{Binding media}

According to Thompson [31], the basic standard binding medium for illuminations in medieval times was glare, which is made from egg white, processed to a watery liquid by certain methods. Furthermore, Arabic gum as well as protein based binders, mostly prepared from parchment, were applied. However, no binding media could be identified in our studies. The main reason may be the chemical similarities of egg white and parchment, since both are proteins and, due to the overlapping of the significant bands in the mid infrared of these compounds, no identification can be achieved by rFTIR. For Raman spectrometry binding media show in general a strong fluorescence.

\section{Conclusion}

Two outstanding codices could be investigated noninvasively by the combination of XRF, rFTIR, and Raman spectrometry. Unfortunately, the period of time for the investigations was limited to several days in contrast to other comparable studies in literature $[3,6]$. The characterization of the precious illuminations of the saints as well as the used inks is of historical importance, as no studies have been carried out so far and no references of investigations of other codices from the Carolingian period could be found.

For the characterization of the parchment only rFTIR spectrometry provided some information about the manufacturing process and treatment of the different folios, e.g., the identification of calcium carbonates and silicates on the surface of the parchment. $\mathrm{CaCO}_{3}$ is an indicator for the liming or whitening of the animal skin, the silicates are due to polishing the surface with pumice. The combination of XRF and Raman spectrometry enabled the characterization of black/brown inks in the text as iron gall ink as well as vermilion and red lead as red inks in the initials of both codices. In some of the black/brown inks oxalates were detected by rFTIR, which indicates degradation of the binding media by mold fungi. The use of complementary methods allowed the identification of typical pigments in illuminations such as lead white, orpiment/realgar, red lead, vermilion and red iron oxides as well as azurite and indigo, together with the rather rare copper chloride hydroxide. The experimental results showed as well that the same palette was used throughout the entire codex.

In general, XRF provided significant information about the elemental composition, which was important for the evaluation of rFTIR as well as Raman spectra allowing the identification of several inorganic pigments. A draw-back of XRF is the lack of compound specific information and the disability to identify organic materials. Furthermore, the penetration depth of X-rays is high, so that the material on the verso side of the analyzed folios contributes to the signal as well. In contrast, compound specific rFTIR was well as Raman spectrometry signals derive mainly from the uppermost surface. However, the identification of various inorganic materials is still not always possible with these methods. rFTIR, e.g., does not detect important metal oxides and sulfide pigments such as vermilion, red lead and orpiment/realgar. On the other hand, rFTIR was the only method allowing the identification of compounds such as calcium oxalate or silicates. During the investigations it turned out that only Raman spectrometry allowed a clear identification of iron gall ink [44], whereas rFTIR did not, although it was possible in sample studies with reference inks.

The scientific data collected from the manuscripts underlined the authenticity of these codices. As the aim of the CIMA-project lies in a general study of different manuscripts and not only in the examination of the codices MMI and MMA, the limited period of time of several days was not sufficient to answer all questions. However, the results obtained so far could yield data which are useful for the historic and philological studies and it seems to extend the analysis with further complementary methods like fiber optic reflectance spectroscopy (FORS) to complete the results.

\section{Abbreviations \\ CIMA: Centre of Image and Material Analysis in Cultural Heritage; HRSM: Hochschul-Raum Struktur-Mittel; IRUG: Infrared and Raman Users Group; ISTA: Institute of Science and Technology in Art; rFTIR: Fourier transform infrared spectrometry in the reflection mode; XRF: X-ray fluorescence; FORS: fiber optic reflectance spectroscopy; MP: measurement point; MMA: Codex Millenarius Maior; MMI: Codex Millenarius Minor.}

Authors' contributions

BF analysis heritage science objects with XRF and interprets results of XRF, Raman and rFTIR with the help of CF, WV and MS; is the lead author of the 
article. CF performs the Raman spectroscopy and WV the FTIR spectroscopy in the reflection mode. Both help writing the analysis results. MS is the coordinator of the project and helps with the interpretation of results, preparation and corrections of this paper. FP is the head of the library in Kremsmuenster Abbey and provides information about the historical background of the analyzed objects. All authors read and approved the final manuscript.

\section{Author details}

${ }^{1}$ Institute of Science and Technology in Art, Academy of Fine Arts Vienna, Schillerplatz 3, 1010 Vienna, Austria. ${ }^{2}$ Kremsmuenster Abbey, Stift 1, 4550 Kremsmuenster, Austria.

\section{Acknowledgements}

This project was realized in the frame of CIMA, an interuniversity research institution with an interdisciplinary approach to the investigation of cultural heritage. The authors are grateful to their partners in the project, especially to Prof. Dr. Heinz Miklas, Prof. Dr. Robert Sablatnig and DI Fabian Hollaus. Special thanks are also due to Prof. Miklas for the proof reading and discussion of the manuscript.

\section{Competing interests}

The authors declared that they have no competing interests.

\section{Availability of data and materials}

The datasets used and/or analysed during the current study are available from the corresponding author on reasonable request.

\section{Ethics approval and consent to participate}

Not applicable.

\section{Funding}

Not applicable.

\section{Publisher's Note}

Springer Nature remains neutral with regard to jurisdictional claims in published maps and institutional affiliations.

Received: 13 October 2017 Accepted: 16 February 2018

Published online: 12 April 2018

\section{References}

1. CIMA is an interuniversity research institution with an interdisciplinary approach aiming at the investigation of cultural heritage and was founded in 2014, see http://hrsm.caa.tuwien.ac.at/. Accessed 22 Feb 2017.

2. Hochschulraum-Strukturfonds-HRSM project "Analysis and Conservation of Cultural Heritage-Modern Imaging and Material Analysis Methods for the Visualization, Documentation and Classification of Historical Written Material (Manuscripts)". Financial support by the Federal Ministry of Science, Research and Economy; 2013.

3. Biccieri M. The purple Codex Rossanensis: spectroscopic characterization and first evidence of the use of the elderberry lake in a sixth century manuscript. Environ Sci Pollut Res. 2014. https://doi.org/10.1007/ s11356-014-3341-6.

4. Aceto M, Agostino A, Fenoglio G. First analytical evidences of precious colourants on Mediterranean illuminated manuscripts. Spectrochim Acta Part A Mol Biomol Spectrosc. 2012;95:235-45.

5. van der Weerd J. Identification of pigments and gemstones on the Tours Gospel: the early 9th century Carolingian palette. Raman Spectrosc. 2004;35(4):279-83. https://doi.org/10.1002/jrs.1148.

6. Brown KL, Clark RJH. The Lindisfarne Gospels and two other 8th century Anglo-Saxon/Insular manuscripts: pigment identification by Raman microscopy. J Raman Spectrosc. 2004;35:4-12. https://doi.org/10.1002/ jrs.1110.

7. Krenn M, Winterer C. Mit Pinsel und Federkiel: Geschichte der mittelalterlichen Buchmalerei. Darmstadt:WBG, Primusverlag; 2009.
8. Brown MP. Illuminated manuscripts: a guide to technical terms. London: Getty Museum and British Library Board; 1994.

9. Holter K, Neumüller W. Der Codex Millenarius. In: Forschungen zur Geschichte Oberösterreichs Band 6, Linz: Oberösterreichisches Landesarchiv; 1959

10. Neumüller W. Der Codex Millenarius und sein historischer Umkreis. In: Jahresbericht des Stiftsgymnasiums Kremsmünster 1960:7-49.

11. Holter K, Neumüller W. Markus und der Löwe. Die Evangelisten und ihre Symbole im Codex Millenarius. Graz: Akademische Druck- und Verlagsanstalt (ADEVA); 1977

12. Holter K. Die alten Bestände der Stiftsbibliothek Kremsmünster. In: Der Österreichische Bibliothekarstag 1980. Biblos-Schriften 114. Wien 1981:46-60.

13. Fill H: Katalog der Handschriften des Benediktinerstiftes Kremsmünster. I. Von den Anfängen bis in die Zeit des Abtes Friedrich von Aich (ca. 800-1325). Wien: Österreichische Akademie der Wissenschaften, phil.hist. Klasse, Denkschriften 166. Veröffentlichungen der Kommission für Schrift- und Buchwesen des Mittelalters II.3.1 1984.

14. Guedes A, Prieto AC. Raman spectroscopy for the characterisation of inks on written documents. In: Chalmers JM, Edwards HGM, Hargreaves MD, editors. Infrared and Raman spectroscopy in forensic science. Weinheim: Wiley; 2011.

15. Derrick M, Stulik D, Landry JM. Infrared spectroscopy in conservation science. Los Angeles: The Getty Conservation Institute; 1999.

16. Bruni S, Caglio S, Guglielmi V, Poldi G. The joined use of n.i. spectroscopic analyses_FTIR, Raman, visible reflectance spectrometry and EDXRF-to study drawings and illuminated manuscripts. Appl Phys A. 2008;92:103-8.

17. Doherty B, Daveri A, Clementi C, Romani A, Bioletti S, Brunetti B, Sgamellotti A, Miliani C. The Book of Kells: a non-invasive MOLAB investigation by complementary spectroscopic techniques. Spectrochim Acta Part A Mol Biomol Spectrosc. 2013;11(5):330-6.

18. Miliani C, Domenici D, Clementi C, Presciutti F, Rosi F, Buti D. Colouring materials of pre-Columbian codices: non-invasive in situ spectroscopic analysis of the Codex Cospi. J Archaeol Sci. 2012;39:672-9.

19. Pessanha S, Manso M, Carvalho ML. Application of spectroscopic techniques to the study of illuminated manuscripts: a survey. Spectrochimica Acta Part B. 2012;71-72:4-61.

20. Hahn $O$. Analyses of iron gall and carbon inks by means of $X$-ray fluorescence analysis: a non-destructive approach in the field of archaeometry and conservation science. Restaurator. 2010;31(1):41-64.

21. Ricciardi P, Delaney JK, Facini M, Glinsman L. Use of imaging spectroscopy and in situ analytical methods for the characterization of the materials and techniques of 15 th century illuminated manuscripts. J Am Inst Conserv. 2013;52(1):13-29. https://doi.org/10.1179/01971360 $12 Z .0000000004$

22. Ricciardi P, Delaney JK, Glinsman L, Thourya M, Facinia M, Riea E. Use of visible and infrared reflectance and luminescence imaging spectroscopy to study illuminated manuscripts: pigment identification and visualization of underdrawings. Optics Arts Architecture Archaeol. 2009. https:// doi.org/10.1117/12.827415.

23. Mounier A, Le Bourbon G, Aupetit C. Hyperspectral imaging, spectrofluorimetry, FORS and XRF for the non-invasive study of medieval miniatures materials. Heritage Sci. 2014;2:24.

24. Muralha SF, Miguel C, Melo MJ. Micro-Raman study of Medieval Cistercian 12-13th century manuscripts: santa Maria de Alcobaça, Portugal. J Raman Spectrosc Special Issue. 2012;43(11):1737-46. https://doi. org/10.1002/jrs.4065.

25. Desnica V, Schreiner M. A LabVIEW-controlled portable X-ray fluorescence spectrometer for the analysis of art objects. X Ray Spectrom. 2006;35:280-6.

26. XGLab S.R.L.—Spinoff del Politechnico di Milano, Milano. 2017. http:// www.xglab.it/. Accessed 22 Feb 2017

27. Bruker Optics, Ettlingen, Germany. 2017. https://www.bruker.com/ products/infrared-near-infrared-and-raman-spectroscopy/ft-ir-routinespectrometers/alpha/overview.html/. Accessed 22 Feb 2017.

28. Griffiths PR, de Haseth JA. Fourier transform infrared spectrometry. In: Winefordner JD, editor. 2nd ed. Hoboken: Wiley; 2007.

29. Infrared and Raman Users Group (IRUG), Philadelphia, USA. 2017. http:// irug.org/. Accessed 22 Feb 2017.

30. Enwave Optronics, Irvine, USA. 2017. http://www.tsi.com/raman-spectrometers/. Accessed 22 Feb 2017. 
31. Thompson D. The materials and techniques of medieval painting. New York: Dover Publications; 1956.

32. Lee AS, Mahon PJ, Creagh DC. Raman analysis of iron gall inks on parchment. Vib Spectrosc. 2005;41:170-5.

33. Bicchieri M, Monti M, Piantanida G, Sodo A. All that is iron-ink is not always iron-gall! Raman Spectrosc. 2009;36:1074-8.

34. Lee AS, Otieno-Alego V, Creagh DC. Identification of iron-gall inks with near-infrared raman microspectroscopy. Raman Spectrosc. 2008:39:1079-84

35. Bicchieri M, Monti M, Piantanida G, Sodo A. Non-destructive spectroscopic investigation on historic Yemenite scriptorial fragments: evidence of different degradation and recipes for iron tannic inks. Anal Bioanal Chem. 2013;405(8):2713-21.

36. Daniel F, Mounier A. Alteration of gildings on mediaeval mural paintings. Proceedings of the ICOM-CC joint interim meeting multidisciplinary conservation: a holistic view of historic interiors. Rome 2010. http://www. icom-cc.org/54/document/alteration-of-gildings-on-mediaeval-muralpaintings/?id=797. Accessed 20 Feb 2018

37. Duran A, Perez-Rodríguez JL, Jimenez de Haro MC, Herrera LK, Justo A. Degradation of gold and false golds used as gildings in the cultural heritage of Andalusia, Spain. J Cultur Heritage. 2008;9(4):184-8.

38. Martin E, Eveno M, Resort C: L'órnement métallique et ses alterations, Maitre de Burgo de OSam, La Vierge et l'Efant entourés d'anges, St. Amboise. Techné. 1998:7:105-8
39. Ricciardi P, Pallipurath A, Rose K. 'It's not easy being green': a spectroscopic study of green pigments used in illuminated manuscripts. Anal Methods. 2013;5:3819-24. https://doi.org/10.1039/C3AY40530C.

40. Mounier A, Daniel F. Pigments \& dyes in a collection of medieval illuminations (14th-16th century). Color Res Appl. 2017;42(6):807-22. https://doi. org/10.1002/col.22146

41. Castro K, Sarmiento A, Martínez-Arkarazo I, Madariaga JM, Fernández LA. Green copper pigments biodegradation in cultural heritage: from malachite to moolooite, thermodynamic modeling, X-ray fluorescence, and Raman evidence. Anal Chem. 2008;80(11):4103-10. https://doi. org/10.1021/ac800255w.

42. Bonaventura M, Del Gallo M, Cacchio P, Ercole C, Lepidi A. Microbial formation of oxalate films on monument surfaces: bioprotection or biodeterioration? Geomicrobiol J. 1999;16(1):55-64. https://doi. org/10.1080/014904599270749.

43. Rampazzia L, Andreotti A, Bonaduce I, Colombini MP, Colombo C, Toniolo L. Analytical investigation of calcium oxalate films on marble monuments. Talanta. 2004;63(4):967-77. https://doi.org/10.1016/j. talanta.2004.01.005.

44. Vandenabeele P, Edwards HGM, Moens L. A decade of Raman spectroscopy in art and archaeology. Chem Rev. 2007;107:675-86. https://doi. org/10.1021/cr068036i.

\section{Submit your manuscript to a SpringerOpen ${ }^{\circ}$ journal and benefit from:}

- Convenient online submission

- Rigorous peer review

- Open access: articles freely available online

High visibility within the field

- Retaining the copyright to your article

Submit your next manuscript at $\boldsymbol{\nabla}$ springeropen.com 